\title{
Urban surface water system in coastal areas: A comparative study between Almere and Tianjin Eco-city
}

\author{
Tao Zou ${ }^{1^{*}}$, Zhengnan Zhou ${ }^{2}$ \\ ${ }^{1}$ Beijing Tsinghua Tongheng Urban Planning and Design Institute, Beijing, China; ${ }^{*}$ Corresponding Author: zoutao@vip.sina.com \\ ${ }^{2}$ School of Architecture, Tsinghua University, Beijing, China \\ Received 12 August 2013; revised 10 September 2013; accepted 17 September 2013 \\ Copyright (C) 2013 Tao Zou, Zhengnan Zhou. This is an open access article distributed under the Creative Commons Attribution Li- \\ cense, which permits unrestricted use, distribution, and reproduction in any medium, provided the original work is properly cited.
}

\section{ABSTRACT}

In the purpose of defining typical urban water management challenges in coastal lowlands in the context of global climate change, a comparative study was conducted between two coastal new towns respectively located in the Netherlands and Northern China. Comparative method is applied to define main functioning patterns of urban water systems in the two cases, then computer simulations were used to further compare drainage capacity in order to reveal the trends of urban water management. Major result has shown that Almere in the Netherlands generally more advanced in urban water management as multiple functioning patterns are available. Strong dykes maintain competence for land subsidence and sea level rise. Open water system decreases local runoff and increases water retention level. Systematic control of sluices and locks which serve for shipping and waterfront landscaping are simultaneously isolating contaminants from outer water body. Tianjin Eco-city in China has shown both strengths and weaknesses. It takes large amount of reclaimed water as main landscaping water source, which adapts to local water pollution and shortage while requires highly centralized facilities. Large water body is reserved and huge scale underground drainage system built, but it is still vulnerable to heavy storms due to the lack of efficient surface water drainage system. Coastal line control does not adequately prevent from increasing storm surge risks in the future. SWMM simulations have supported the viewpoint of distributed surface water with a higher efficiency for storm drainage. Meanwhile, surface water system returns more added values to urban development. The study is corresponding well with the theory of water sensitive city. As a conclusion, urban water system should always incorporate methods to achieve higher system resilience based on multiple functioning patterns.

Keywords: Urban Surface Water System; Urban Water Management; Coastal Areas; SWMM

\section{INTRODUCTION}

\subsection{Vulnerability of Coastal New Towns}

Coastal zones are highly vulnerable to sea level rise in the context of global climate change. Stronger and higher frequency of storm surges poses an increasing threat to coastal urban area, and especially to the infrastructure systems. The main issues include flooding, water resources, land loss and water quality as well. Sea level rise may cause immense economic loss due to the direct or indirect damage to the urban areas, sewers, ports and other infrastructure. In China, many coastal lowlands have limited or no human-built protection against impacts from sea level rise or storms. Simultaneously the quality of water is likely to decrease, with the fluctuation of runoff that either increased sediments and pollutants or decreased flushing that leads to higher salinity levels. In north China coastal cities, increased salinity is vastly threatening water quality for residential users, and affecting crops as well.

Cities located in coastal regions are very vulnerable to extreme weather events. While in recent years, large number of new commercial and residential development in China accelerates the concentrations in coastal areas. In megacities like Shanghai and Tianjin, or city clusters located around them, dozens of new-towns with a 
planned population from 100,000 to 500,000 emerges along coastal low-lying belts, among which Sino-Singapore Tianjin Eco-city is one of the most known projects in China.

Without adequate consideration on the rising risks, the vulnerable costal lowland area has been developed into new settlements. The phrase "Wrong location" is commonly used when arguing on coastal new towns' planning. But decision maker's faithful submission to the rule of urban concentration has led to the adaption of these "wrong places" unavoidable.

Looking back into the near history, European cities had also experienced such fast growing period decades before. Almere is one of them. As an extension of Amsterdam city, Almere is still considered to be located wrongly due to geological reason [1]. But fortunately enough, Dutch seems far more experienced in coping with coastal risks.

\subsection{Introduction on the Study}

A comparative study was conducted between two coastal new towns respectively located in China and the Netherlands (Figure 1). The purpose is to define typical challenges and the differences between these urban developments in coastal lowlands. Local strategies for planning the urban surface water system and their functioning patterns differ greatly according to local climate and other social-economic situations. In order to further discuss on possible future adaption to extreme weather events, a brief SWMM simulation was applied to each case, so as to compare the two methodologies coping with the same water issues. The comparison intentionally implicates the better orientation of urban water management in different phases of urban planning.

\section{PRELIMINARY STUDIES AND METHODS APPLIED}

\subsection{Cases General Information}

\subsubsection{Almere of the Netherlands}

Initially built as a satellite town of the capital Amster-
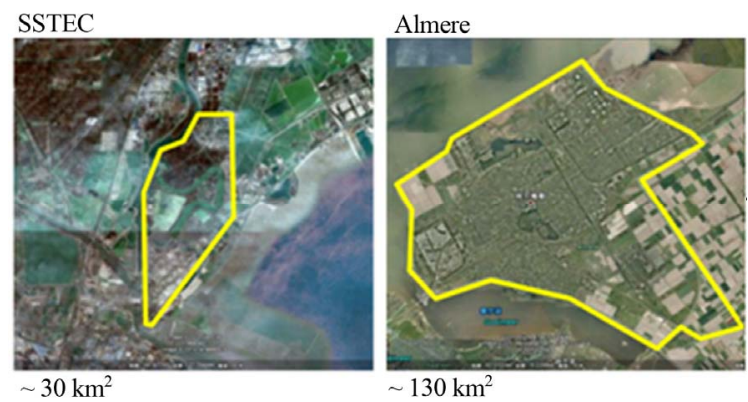

Figure 1. Same scale satellite images of Tianjin Eco-city and Almere. dam, Almere is located in Flevoland of the Netherlands, $20 \mathrm{~km}$ away from Amsterdam. The city covers 248.77 $\mathrm{km}^{2}$ in total, including water area of $118.29 \mathrm{~km}^{2}$. As the largest city of Flevoland, Almere has become the seventh largest city in the Netherlands with the population over 180,000 by July 2008 . Owing to the expansion plan of Almere, its population is expected to reach 350,000 by 2030.

Almere is a typical polder city. The sea reclamation project in Flevoland is initially planned for agricultural purpose. After the end of World War II, two new polder cities were planned because of the rapid population growth and the increasing house demand. One is Lelystad, and the other one is Almere. As one of the latest built cities in the Netherlands, with the first building emerged in 1976, Almere was formally established as a municipality until 1984.

\subsubsection{Sino-Singapore Tianjin Eco-City}

Sino-Singapore Tianjin Eco-city (SSTEC, or Tianjin Eco-city) is an international cooperated new town development started from 2008 . The $34.2 \mathrm{~km}^{2}$ of coastal salinized lowland was chosen in consideration of preventing from taking up farmlands in the region. The first phase covers $7.8 \mathrm{~km}^{2}$ of development capable of accommodating 105,000 residents in 2015 , then 350,000 residents or 110,000 families by 2030 when fully built.

Aiming at a demonstration project of sustainable urban development in China, Tianjin Eco-city is seeking for environmental friendly and low-impact development. Work-life balance and compact-mixed land-use structure, as well as sustainable mass transit system has been largely considered. Water recycling due to regional water shortage is also taken as one of the most important strategies. Large scale reclaimed water plant has been built, and storm water drained through huge scale underground piping system.

In the past years, a few families moved into the new eco-city, while national level economic policy has lowering down the pace.

\subsection{Climate and Topographical Backgrounds}

Both located in the temperate zone in northern sphere, Almere has higher latitude of $52.37 \mathrm{~N}$, while Tianjin Eco-city locates $39.15 \mathrm{~N}$. Although much to the south, Tianjin has an annual average temperature not much higher than Almere. The major difference is a colder winter and a much hotter summer in Tianjin.

Annual precipitation in Almere is a bit higher than Tianjin. With a lower annual actual evaporation, Almere shows a wet climate in general. In Tianjin, more than $70 \%$ precipitation is received during the hot summer period, and throughout remaining months of the year it 
appears very dry. Tianjin is now facing severe water shortage due to high population density and general dry climate as in other northern cities in China (Table 1).

Topographically, Almere is a polder city lying several meters lower than sea-level. The polder is prevented from flooding by strong dykes along the periphery of inside lowlands. Tianjin Eco-city was historically consisting of salt fields and a large contaminated reservoir. Dykes for defensing storm surges lie near its border. The whole area is quite flat and mostly around $1 \mathrm{~m}$ above sea-level, which will be raised to around $3 \mathrm{~m}$ according to its master planning.

\subsection{Future Challenges for the Two Cases}

Future dilemma in sustainable development for both coastal new-towns is obvious. Among many of the main problems encountered, the following ones are the most harmful and urgent.

\subsubsection{Storm Tide}

Storm tide is one of the most challenges in the context of global climate change. As about two thirds of land in the Netherlands is highly vulnerable to flooding, it is very important to develop on the reclaimed land following the huge scale damming. Luckily enough, the risk of storm tides for Almere has been tremendously overtaken by the two dams of Afsluitdijk and Houtribdijk. In contrast, Tianjin Eco-city is situated much adjacent to Bohai Bay with one and only dam about $500 \mathrm{~m}$ away from its southeastern border. Strong tide had historically hit part of the site, and future extreme weather event is threatening this area still.

\subsubsection{Land Subsidence}

Land subsidence is another important issue. Three quarters of the Netherlands is subsiding, the young and flexible soil of Almere is subsiding even more rapidly.
This process is even intensified by drainage and construction, and can only be stopped by the construction of large water storage facilities. In Tianjin, as part of the most densely populated area in Northern China, deep ground water over-exploitation has led to severe land subsidence. This problem overlaps with sea level rise, and has enormously downturn capability of dams originally built for 100 years return period to a much lower level.

\subsubsection{Water Shortage}

Freshwater resource might not be an issue for Almere due to abundant and evenly distributed precipitation, while Tianjin is facing severe shortage of freshwater during most months in a year and suffers from heavy storms in summer period. Water pollution and saline soil for Tianjin Eco-city are also higher risks for keeping a good urban living quality.

\subsubsection{Extreme Weather Event}

Almere is naturally a part of a polder that totally relies on the largest pumps in the world, while Tianjin Eco-city is more densely developed with much heavier rains during the summer period. Extreme weather event, an unprecedented rainfall, could be a rigorous challenge to both cities.

\subsection{Comparative Methods Applied}

\subsubsection{General Research Framework}

When studying on urban surface water system, it will naturally relate to other urban water management issues. Ground water and urban infrastructures immensely affects surface water system, while only the latter one shows more obvious clues to all who concerns urban form. This might also be the reason why urban planners, in a conventional manner, takes care more on surface water system, and feel less responsible on other unseen

Table 1. Climate and topographical information for both cases.

\begin{tabular}{|c|c|c|}
\hline & Tianjin Eco-city (Tanggu) ${ }^{\mathrm{a}}$ & Almere (Amsterdam) $)^{\mathrm{b}}$ \\
\hline Longitude & $117.75 \mathrm{E}$ & $5.22 \mathrm{E}$ \\
\hline Latitude & $39.15 \mathrm{~N}$ & $52.37 \mathrm{~N}$ \\
\hline Annual average temperature & $13.0^{\circ} \mathrm{C}$ & $9.6^{\circ} \mathrm{C}$ \\
\hline Coldest month average temperature (Jan.) & $-3.0^{\circ} \mathrm{C}$ & $2^{\circ} \mathrm{C}$ \\
\hline Hottest month average temperature (Jul.) & $26.8^{\circ} \mathrm{C}$ & $18^{\circ} \mathrm{C}$ \\
\hline Annual precipitation & $545.4 \mathrm{~mm}$ & $755 \mathrm{~mm}^{\mathrm{c}}$ \\
\hline Annual actual evaporation & - & $563 \mathrm{~mm}^{\mathrm{c}}$ \\
\hline Annual evaporation from water surface & $2025.4 \mathrm{~mm}$ & - \\
\hline
\end{tabular}

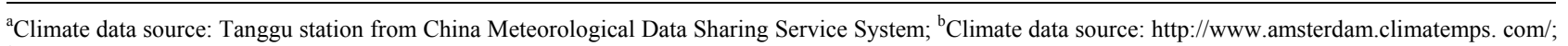
${ }^{c}$ Reference [2]. 
issues. The comprehensive framework of the general program excludes the possible bias. Surface water is directly supported by ground water and infrastructure system (Figure 2).

\subsubsection{Information-Based Mapping and Structuring}

In order to understand the urban water systems accurately and concisely, structures of these urban water systems have been firstly divided into single elements. These elements were reproduced into ArcGIS and SWMM, thus to form the whole information-based picture of the urban water systems. Data had been collected mainly via site visits and satellite image interpretation, while contribution from local planning authorities and institutes greatly helps to build up a more credible and precise mapping.

\subsubsection{Theory of Water Sensitive City}

Based on the general urban planning philosophy, urban water management issues are always complex and case sensitive. Thus initial works on the comparison of the operational modes and functions for the two urban water structures are largely related with local situation, in spite of considering the incomparable preconditions that might confuse the results. Introduction of the theory of water sensitive city has apparently clarified the comparative framework. A dimension of time has been added, and the two urban water management systems have been seen evolving.

\subsubsection{SWMM Modeling}

SWMM modeling focusing on storm water drainage helps further to compare the different structures. As many parameters had been hypothetically setup due to

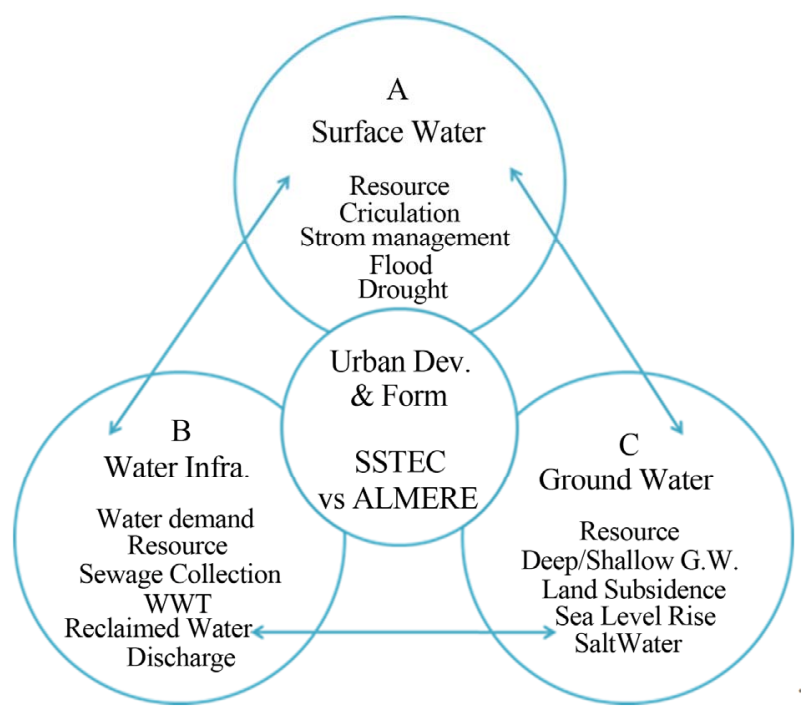

Figure 2. General research framework. the lack of precise topographical data, the touch-and-go type of modeling is far from accurate. Thanks to the high similarity of for both cases though, the model fulfills the basic requirements of an urban study at this specific level.

The basic concept is to study on how spatial structure of the systems would affect the storm water drainage efficiency, rather than how pipelines or waterways should be designed. Modeling for both cases is limited to a "proper scale". In the case of Almere, only main waterways are modeled, not any capillary surface water networks or underground storm water pipes have been taken into account. Same in Tianjin Eco-city, drainage pipelines within main sub-catchment area are not included.

Almere Stat, the center part of Almere, has been simulated instead of the whole large region. Rainfalls have been assumed to be the same event cluster, which is 5,10 and 50 years return period in Tianjin.

\section{STRUCTURE AND FUNCTIONS OF THE URBAN SURFACE WATER SYSTEMS}

\subsection{The Case of Almere}

Almere is planned with several semi-independent core areas with blocks, public facilities and location markers. These core areas are connected to the urban center through the public infrastructures. Ditches and various kinds of water bodies intersect in the six urban areas of Almere. The highly efficient surface water system of the polder city is protecting the land from damage, and maintaining social and economic development within this region.

\subsubsection{Structure of Surface Water System}

1) Lakes

Almere is surrounded by water in three sides. The lake Markermeer in the north is the twin lake of IJsselmeer built in the early Zuiderzee Works. The Markermeer covering $700 \mathrm{~km}^{2}$ is 3 to $5 \mathrm{~m}$ in depth. Due to economic and ecological concerns, the area that initially planned to build polder turns to form a lake after building a dam. Nowadays, the Markermeer functions as fresh water reservoir, buffering for drought and flood control, and ecological conservation as well. IJmeer in the west converges with the Markermeer; lake in the south is Gooimeer. The three external lakes' water level is very close to sea level.

The entire Almere is below the sea level, and the road elevation is -6.2 to $-3.15 \mathrm{~m}$ N.A.P. The overall terrain of the planning area is relatively flat; most high-lying areas are located in the southwest; low-lying areas are located in the north. Lake Weerwater in the central part covers 
$1.5 \mathrm{~km}^{2}$; Lake North (Noorderplassen) covering $2 \mathrm{~km}^{2}$ is a wetland protection park.

2) Drain and Ditches

The polder in which Almere locates carries dense river network that are mainly functioning as drain and ditches, including high canal, low canal, normal river ways and capillary water net.

High canal, of $50 \mathrm{~m}$ in width, collect seepage water and rainwater from higher ground in the south and direct to Ketelmeer in the east. Owing to the large amount of seepage water here, regular flow of high canals is significant to security, ecology and recreation. Low canals, of $45 \mathrm{~m}$ in width, collect excess surface water from lower flow rate area in the middle of polder and use it to adjust the water level. The water quantity of canal is under control, and the water quality is ensured by continuous refreshing water. The large part of Almere is located at west of the two canals. The staggered network of water in the region plays a significant role to maintain the quantitative and qualitative balance of local water system.

\section{3) Pumping Stations}

Pumping station de Blocq van Kuffeler is one of the largest pumping stations in the world. It is located on the dam where high and low canals meet in the northeast of Almere. The huge structure is put into use in 1967, which is diesel-powered. It maintains the polder's water elevation with other three pumping stations in Flevolands.

The pumping station comprises four pump units. It works at $85 \mathrm{rpm}$ under normal conditions, with processing capacity from 700 to $850 \mathrm{~m}^{3} / \mathrm{min}$. The pump unit can work for 600 to 900 hours during the dry season, and 1200 hours during the rainy season.

4) Weirs and Sluices

Weirs are mainly used to adjust the water level. Movable weirs are adopted to better control the height of the regulated water. This kind of weir, with a movable flap valve, allows excess rainwater passing through the weir in the condition of heavy rainfall, and then the water surface elevation gets back to the present level. Most of the weirs are automatic or semi-automatic. Water is directly discharged into the canal through the weirs.

\subsubsection{Operational Modes and Function Analysis}

As a typical polder city, the basic goal for Almere is to maintain a long-term stability of surface water level in the polder. This is essential not only to ensure safety of the city with an expected population of 350,000 in the future, but to exert the functions of urban water system in ecology, recreation and transportation. Water quality must be kept in good conditions to fully achieve these functions.

A key climate feature of the region is the relatively even distributed rainfall all the year round, with a sig- nificant difference of evaporation between winter and summer. Therefore, "flood in winter and drought in summer" emerges regularly, and the urban water system can be roughly defined as two "operational modes": "winter mode" and "summer mode". In colder seasons, excess surface water is discharged from the polder to the outside water body, so as to prevent flooding from occurring in reclaimed land for urban construction and agricultural use; in warmer seasons of the year, external water is introduced to the polder to ensure stability of regional hydrological system, and to meet agricultural water demand and protect dams from damage as well. In different management regions, the internal water level control in winter and summer are mostly the same, with some slight difference in certain area. Throughout the year, "winter mode" is generally longer because the average annual rainfall $(755 \mathrm{~mm})$ is exceeding the total evaporation (563 mm) up to $192 \mathrm{~mm} \mathrm{[2]} \mathrm{(Figure} \mathrm{3).} \mathrm{In}$ addition, when rainstorm comes, the water system in the polder will turn to "flood relief mode" which pose greater challenge to the system's draining efficiency.

Almere and the polder's water system implements three important functions in these operating modes, which show great hints for future urban development of coastal areas.

1) Damming System: Defense Seawater Intrusion

Almere is under the protection of three dams, respectively built in the projects of the Ijsselmeer formed in the early Zuiderzee Works, the Markermeer formed in the Markermeer project, and the south Flevoland polder project. These dams have completely prevented seawater intrusion.

The standards on hydraulic engineering design and construction in the Netherlands are extremely high. The

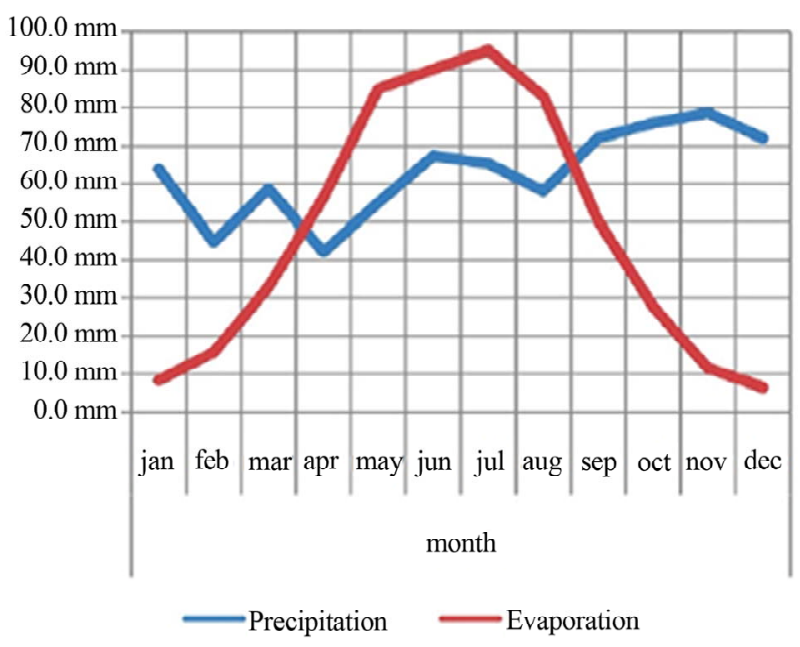

Figure 3. Averaged monthly rainfall and precipitation in millimeters (1971-2000) over the period of one year in the Netherlands. Well visible is that the evaporation is exceeding the precipitation during the summer months [2]. 
$32 \mathrm{~km}$-long Afsluitdijk was completed in 1932 under the design standard of flood with recurrence interval of ten thousand years. It is $3.5 \mathrm{~m}$ higher than the given highest tide, and $90 \mathrm{~m}$ wide at the sea level, equipped with strict impermeable measures. The dam is still intact even it has experienced maritime storm surges for many times [3].

The Markermeer project has not been fully completed, but the $28 \mathrm{~km}$-long Houtribdijk dam becomes the second line of defense. Markermeer is also a key buffer and protection element for this region. In 2003, the Netherlands suffered a severe drought and many dams were threatened. Water was transferred from Markermeer to surrounding polders imminently, which effectively kept the soil moist and ensured the dam safe.

The multi-layer dam system under scientific and strict management is quite sufficient to handle the storm surges that may increase in the future, and to deal with coastal problems caused by land subsidence and sea level rise.

2) Highly Expanded Open Water System: Higher Resilience Dealing with Floods

The standard drainage capacity of the Netherlands can be converted as $14 \mathrm{~mm}$ rainfall drainage per day, and the designed drainage capacity of Flevoland polder is 11 to $18 \mathrm{~mm}$ per day [4]. This drainage standard is very high, but still difficult to resist occasional heavy rain. For example, 24 hours rainfall in parts of the Netherlands had reached $130 \mathrm{~mm}$ in September 1998, which exceeded the drainage capacity and resulted in flooding in extensive agricultural and urban areas. Over the past few years, such situations made the Netherlands lose billions of euros [5].

These make people realize that a climate proof rainwater management method has to ensure a sustainable and flexible rainwater management system in the polder. The system may achieve selective storage in clean rainwater season, and realize rain flood regulation and storage under extreme precipitation. Although maintaining larger open water area may limit urban development and building use, it is almost impossible to result in rainwater infiltration and underground storage because of the higher water table, small drying height and non-permeable soil structure in the polder. Therefore, expanding use of open water to capture and store rainwater is widely recognized. Based on the Netherlands' guidelines for water resources management in the future, local water affairs management institutes keep the following idea: in the new urban development, open water shall account for $10 \%$ of the total land area [6]. In the Flevoland polder, the early open water accounts for only $1 \%$, this is currently expanded to $4 \%$. In the region of Almere with concentrative construction, nearly $4 \mathrm{~km}^{2}$ lakes within the polder in the northern, central and southern parts and the ditches all over the city become important buffer water to deal with storm disaster. Large water storage facilities and extensive open water system greatly reduce surface runoff, as well as construction and operational costs of urban infrastructure.

3) Dynamic Closed Water System: Self-Cleaning Internally

Water management system for Netherlands polder is based on considering each polder as an independent water system, which is mainly to control the stability of the groundwater and surface water elevation. Because of climate reason, the stability of the water level within the polder cannot be self-sustaining. In winter with less evaporation, the excess rainwater will be pumped into the canal at higher terrain, and ultimately discharged into the external lake. The process is reverse in summer, water must be introduced from external lakes, so as to add water and prevent the water level lowered. The control process is effective to ensure stable water quantity, maintain boating conditions, coastline landscaping and ecological services. Simultaneously, it is able to separate water within the polder from pollutants out in the external water bodies.

Nevertheless, researchers are still working on the sustainability of water management system. The system is still lacking of sufficient inherent resilience, a large amount of relatively clean rainwater is discharged, but much polluted external lake water is also introduced inward in the opposite case. Thus, there is certain risk of water quality decrease. So there comes a challenge to avoid cleaner internal water being discharged, and to prevent external pollutants from canals and rivers. In order to achieve this goal, expanding the open water is an important way to collect clean rainwater, as much as possible. However, for the purpose of maintaining good inter-seasonal water quality in a closed system, sewage plant should be fully used and its drainage standards should be improved. Besides, hygrophyte around the lake shall be used to purify the water, such as reed in ponds and ditches.

At the same time, the so-called "circulation model" [7] for sub-areas is vastly established in Almere in accordance with the water level control. This method is not only conducive to water quality maintenance at low cost, but also improve the quality of urban landscape.

\subsubsection{SWMM Simulation Overview: The Case of Almere}

Total sub-catchment area of Almere Stat is $26.17 \mathrm{~km}^{2}$. It has been divided into 58 sub-catchment areas. 2 retention water bodies have been settled. Main waterways width from 35 to $40 \mathrm{~m}$, branch waterways width from 15 to $27 \mathrm{~m}$, distributes with a total length of $29.5 \mathrm{~km}$ (Figures 4 and 5). 


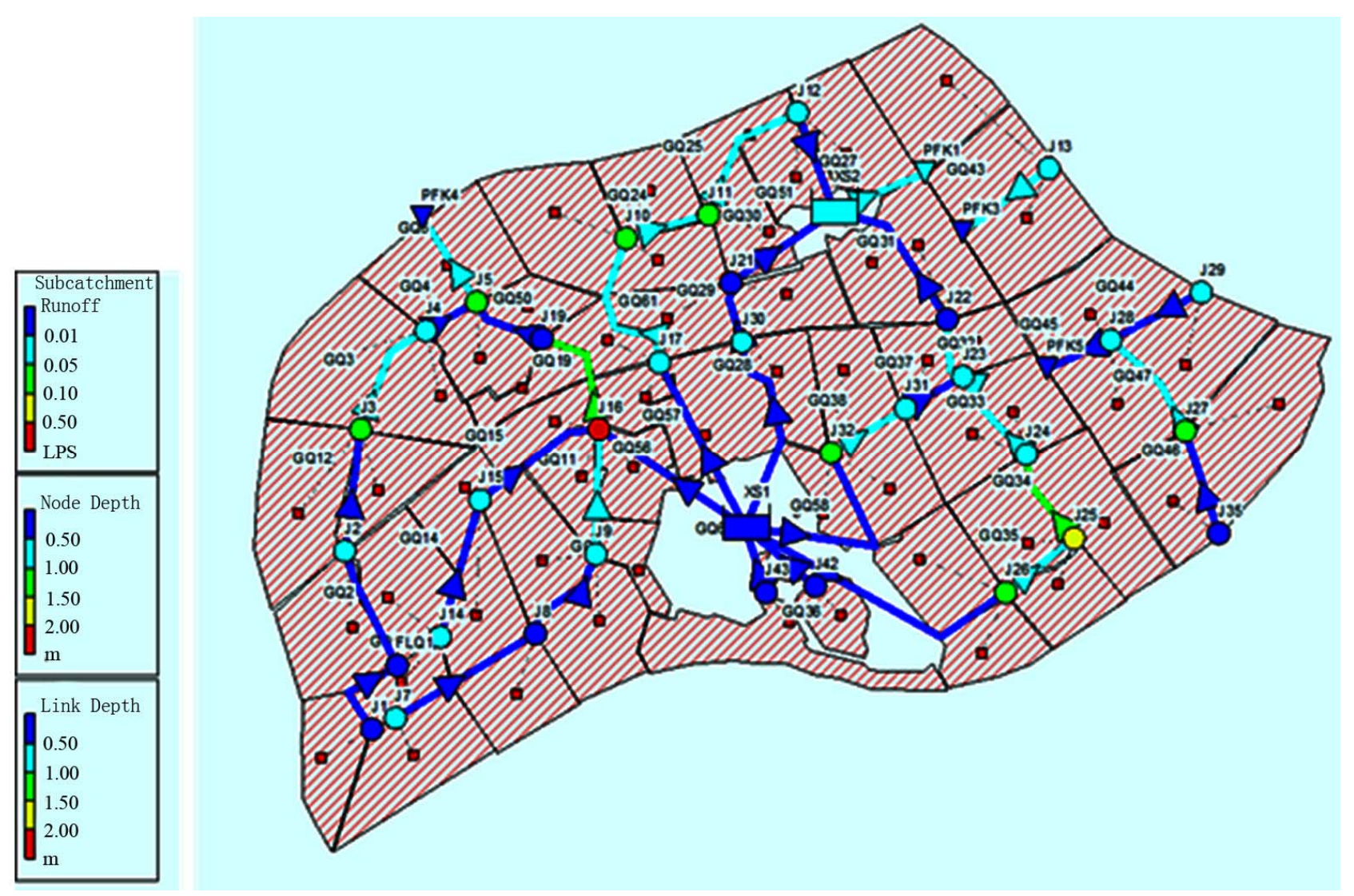

Figure 4. Overview of a SWMM simulation for Almere stat.

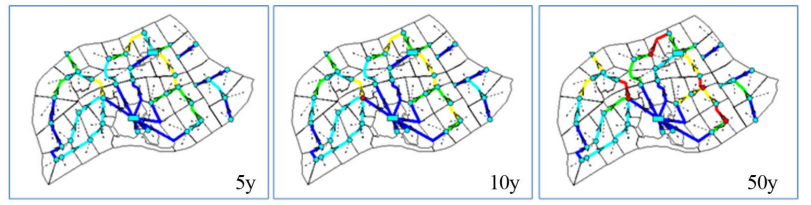

Figure 5. Simulation based on different storm events in Almere Stat. Red dots and lines indicates overflow where flooding will occur. In Almere, nowhere turns red under 10-year return period rainfall event. Small proportion of waterways will overflow under 50-year return period rainfall event.

\subsection{The Case of Tianjin Eco-City}

\subsubsection{Structure of Surface Water System}

1) Lake and Old River Course

Qingjing Lake is located in the center of Tianjin Eco-city. The original reservoir area covered $7.7 \mathrm{~km}^{2}$ in total. The original water body named Yingcheng Reservoir was artificially built on low-lying shallow water with an average depth of $3 \mathrm{~m}$. It had been used as an industrial waste water basin in the past decades. The water covering area varies greatly between rainy season and dry season. When reconstructed and transformed to Qingjing Lake according to the master plan, the total area is reduced to only $1.3 \mathrm{~km}^{2}$.

Jiyunhe old river course flows through Tianjin Eco- city. It was part of Jiyunhe River till a curve cut-off project had been implemented for the purpose of flood control in the near history. As a result, Jiyunhe old river course winds around the central water body for $11 \mathrm{~km}$ in the planning area, and the new watercourse defines the site border. Its water quality is among the worst before being reconstructed as planned. The width of Jiyunhe old river course varies between 150 to $350 \mathrm{~m}$.

The water body consisting of Qingjing Lake and Jiyunhe old rover course is around $4 \mathrm{~km}^{2}$, nearly $12.8 \%$ of total site area, which is one of a feature that most other similar type of urban development not likely to exceed.

2) WWTP

With the key target of water conservation, Tianjin Eco-city attaches great importance to the establishment of water recycling system. Through the construction of systems for sewage treatment, water reclamation, rainwater collection and seawater desalination, the non-traditional water use ratio is planned to reach $50 \%$ by 2020 . The initial capacity of the water reclamation plant is 21,000 tons per day, and the designed capacity is 42,000 tons per day.

\section{3) Pumping Station}

Pumping stations were planned to build at both end of the Jiyunhe old river course, in the purpose of balancing 
interior water amount and quality control as well. The whole interior water body is thoroughly connected without weirs or sluices.

Considering reasonable circulation, another solution is also under discussion: a two-way pumping station built in upper end of the Jiyunhe old river course, and a sluice placed at the lower end.

4) Isolated Ponds

The whole urban surface water system consists predominantly with large water body, and there's only two planned isolated ponds loosely connected with Jiyunhe old river course. These waterway-like ponds were planned to be ecological corridors connecting inside water body to the peripherals. But since they are locating higher, serving like a catchment border, rain water will not be collected through natural processes. Their actual function is more visually driven rather than a green ecological corridor.

5) Rain Water Piping System

Rain water is generally collected via piping systems divided in 4 sub-regions. Within each sub-region, very large section pipes and tunnels are densely distributed and deep buried into ground. The largest section can be up to nearly $16 \mathrm{~m}^{2}$, and bury more than $3 \mathrm{~m}$ deep at the outlet of each sub-region. Storm water is then pumped out into the lake and old river course. The whole system is built like a waterway system underground.

\subsubsection{Operational Modes and Function Analysis}

The case of Tianjin Eco-city has chosen specific measurements in coping with the urban water functioning patterns. The basic logic can be seen as highly concentrated system with large scale planning and design.

1) Water Reclamation as Main Water Resource

The first and the most featured functioning pattern is taking large amount of reclaimed water as main water resource, thus simultaneously transforming a waste water basin into a clean water body for urban landscaping and recreational purpose. This substantially adapts to water pollution and shortage situation that might as well exists in other regions. But it requires highly centralized waste water treatment facilities and strictly monitored outlet water quality in accordance with the scale and sustainable target.

In late summer, water quality in Jiyunhe River is the best of a year owing to abundant precipitation in the region. It is the best period of time to pump water from external water body to Jiyunhe old river course so as to replenish water for the interior water bodies. In the rest of a year, reclaimed water from the water reclamation plant will be used for replenishment. Water from the Qingjing Lake will also be directed to the water reclamation plant for processing when its quality degrades.

Presently, water output from the WWTP meets First
Class B, which will be improved to First Class A in the future. According to First Class A, the N, P concentration limits will be able to achieve that of the National Reclaimed Water Quality Standard, but the salinity could still be very high. Therefore, WWTP outlet water should then send for membrane treatment processes in the water reclamation plant to meet Reclaimed Water Quality Standard.

The high salinity of water output from sewage treatment plant is another challenge. It is primarily caused by the following reasons: high salinity of underground water; serious leakage problems of old drainage pipe systems in Hangu and surrounding areas; pipelines passing through many abandoned salt fields, which make the high-salinity underground water leak into drainpipes; high-salinity effluent from surrounding chemical plants also connecting to drainage pipe system, and eventually discharged to the sewage treatment plant.

2) Circulation model as a Way against Eutrophication

At present, the water body of Qingjing Lake circulates counter clock, with the water reclamation plant in-taking water in the north and discharging in the south. The water body of Jiyunhe old river course circulates clockwise. Qingjing Lake and Jiyunhe old river course are connected by culverts and pumping stations. However, the bottom of Qingjing Lake is high in north and low in south, which is not conductive to reverse circulation by itself. On the other hand, for the southwest section connecting Jiyunhe River to Jiyunhe old river course, water quality tends to degrade due to poor liquidity.

In master planning, two connecting ends of Jiyunhe old river course and Jiyunhe River will be built with pumping stations for water exchange. However, the current strategic tendency is that the north end being equipped with a two-way pump which is able to drain and replenish, and the south end built with a sluice.

3) Large Area of Water Body Serve for Visual Landscaping

Large volume of water body is planned, but the designing purpose is originally intended to be more visually rather than ecological functions. As the main water body is relatively concentrated, the site is still vulnerable to heavy storms due to the lack of efficient surface water drainage system.

\subsubsection{SWMM Simulation Overview: The Case of Tianjin Eco-City}

Total sub-catchment area of Tianjin Eco-city is 19.04 $\mathrm{km}^{2}$, which has been divided into 4 main sub-regions according to the planning. Main pipelines diameter ranges from 1.2 to $2.2 \mathrm{~m}$, piping tunnels section area from 5 to $16 \mathrm{~m}^{2}$ with a total length of $63.2 \mathrm{~km}$ (Figures 6 and 7). 


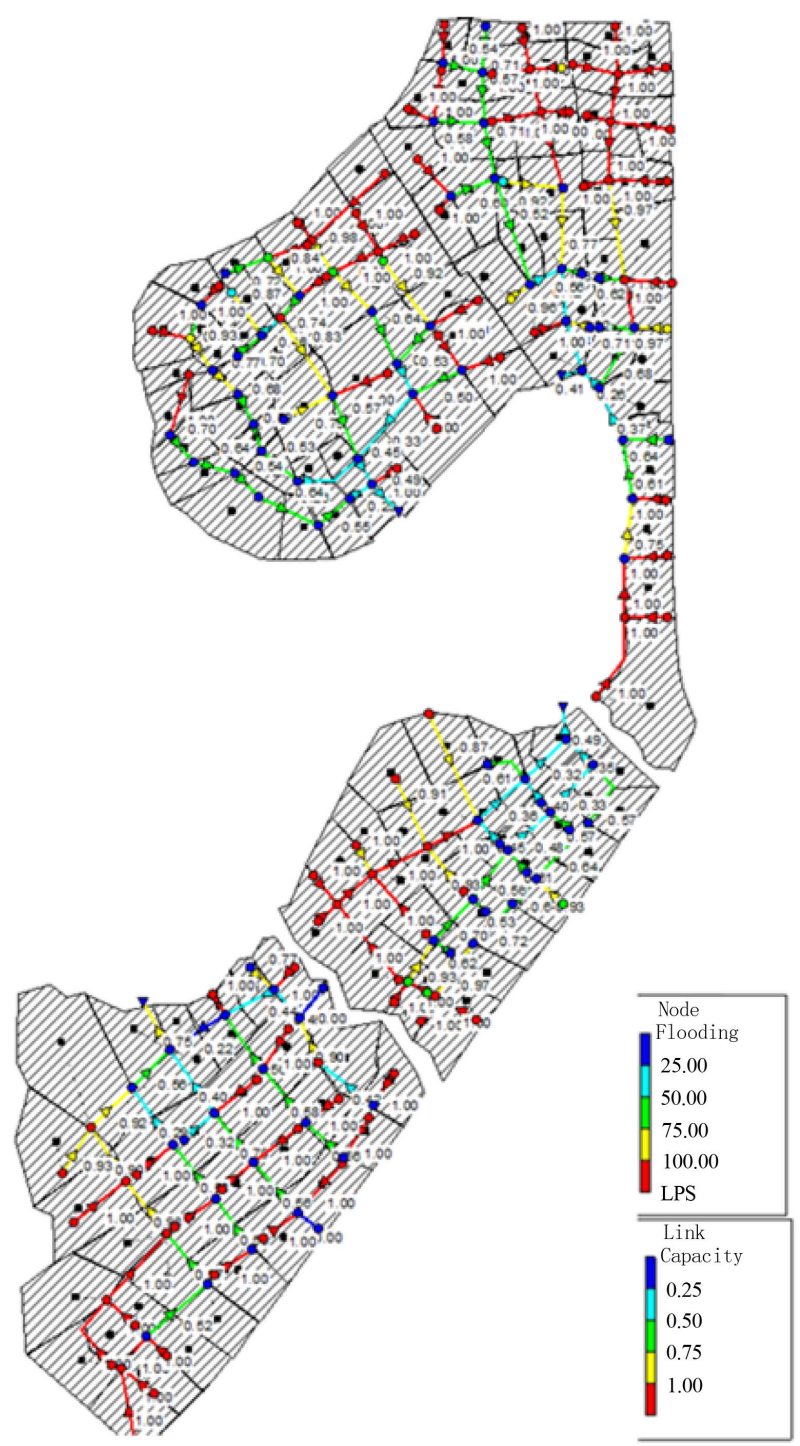

Figure 6. Overview of a SWMM simulation for Tianjin Ecocity.

\section{DISCUSSION}

\subsection{Largely Distributed Surface Water System Gains Higher Drainage Efficiency}

Storm water drainage system in Tianjin Eco-city is one key feature in its master planning. The scale and design size of the piping networks are surprisingly huge. However, deeply buried pipelines and tunnels have apparent bottleneck effect in terms of the drainage efficiency. Namely, they couldn't drain properly once a pipeline is fully loaded, blocked or poorly drained.

This will not occur to open watercourses which are more flexible. Most waterways in Almere are built with rectangular cross-section and trapezoid revetment. Therefore, their watercourses have certain degree of flexi-

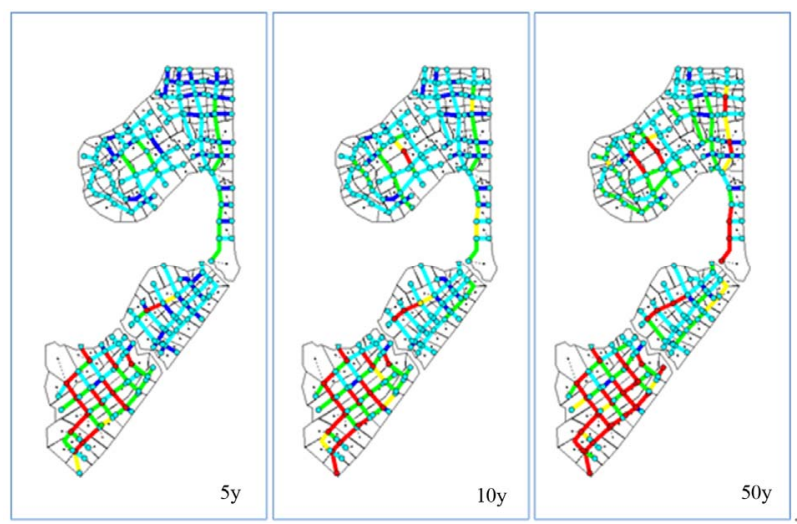

Figure 7. Simulation based on different storm events in Tianjin Eco-city. Red dots and lines indicates overflow where flooding will occur. A large proportion of drainage pipes and tunnels turn red under 10-year return period rainfall event. Massive overflow occurs under 50-year event.

bility capacity in case of heavy rains. Especially, revetments formed on the basis of natural slope protection have inhibiting effects on water surge problems.

It can be seen from the simulation for the above two cases, the widely distributed surface water system of Almere is more efficient with less overloading problem in the drainage path under the same rainstorm reoccurrence period. Furthermore, the two cases are extremely different in utilization effects, although both of them have large open water body. In Tianjin eco-city, converge of water in sub-catchments ultimately flows to the deeply buried pipes, and eventually pumped to the lake. This poses main challenge to the drainage efficiency.

The widely distributed open water network shows obvious advantages to improve drainage efficiency, increase flexibility and ensure stability.

\subsection{Surface Water System Takes up Some Land but Returns Added Value}

Open surface water system will take up some of the urban space, which may be an overly extravagant choice for high-density urban area. However, parks and greenbelts are essential for planning for most proportions of the urban development areas. These open spaces can be combined with water or low-lying land, and will form attractive urban space. In this case, the urban space occupied by the open water system will return added value in another good way. It can be seen from Almere, the open water system combined with the lake forms a waterfront space for the city, which is more comfortable and interesting than a vast open water area.

\subsection{Both Cases Are Specifically Developing towards Water Sensitive City}

The theory of water-sensitive city provides us a way to 
understand the development course of urban water system management. Tianjin Eco-city, as a case of emerging economy, can be considered as the development stage just entering the drained city from a sewer city. Almere, also as a typical polder city, has developed into a waterway city in advance. From this point of view, Tianjin Eco-city shall take Almere as an example to learn from.

Tianjin Eco-city is suffering serious water scarcity which restricts its development. It has put forward the planning program of taking full use of reclaimed water, which to some extent is transforming to a water cycle city. In this aspect, Tianjin Eco-city seems more advanced. It may also be a reference to the future city development.

\section{CONCLUSIONS}

With higher frequency of extreme climate events, global climate change is challenging the urbanization process and population concentration in coastal zones. Although there are many differences in premises and backgrounds comparing with Asian coastal cities, Dutch polder cities have demonstrated the potential dealing logic and operation methods under extreme cases.

Almere with its typical layout of polder city, dispersed settlements, dense river network, large area of open water body, precise control of water level, efficient drainage system, sound damming system, provides us with many experiences in coping with the potential coastal risks in low-lying areas. For the many coastal new town construction projects in emerging economies, such as Tianjin Eco-city, more skills must be acquired to prevent seawater intrusion, to maintain internal water balance, and to achieve good water quality, so as to lay a more solid foundation for urban sustainable development locally and globally.

Climate challenges will be a long-term issue for coastal cities that are seeking for larger and denser developments. In the coming decades, the necessities for learning how to adapt to larger range of uncertainty are crucial requirements for urban planners. As a conclusion, the urban water system planning should always incorporate methods to achieve higher system resilience based on multiple functioning patterns.

\section{ACKNOWLEDGEMENTS}

Thanks to H. M. de Brauw for discussions on related models. Also thanks to Mingyi Li, Jiexin Cheng for their help on calculation and simulation studies, thanks to Jianjia Wang for her translation work.

The project is supported by International Science \& Technology Cooperation Program of China (2010DFA74490).

\section{REFERENCES}

[1] Hooimeijer, F.L., Meyer, H. and Nienhuis, A. (2005) Atlas of Dutch water cities. Sun Architecture, Amsterdam.

[2] Schuetze, T. (2011) Climate adaptive urban design with water in Dutch polders. Water Science and Technology, 64, 722-730. http://dx.doi.org/10.2166/wst.2011.688

[3] Zhou, C. (1987) Helan shuili guanli gaishu. Guangdong Hydropower Technology, 1.

[4] Schuetze, T. and Chelleri, L. (2013) Integrating decentralized rainwater management in urban planning and design: Flood resilient and sustainable water management using the example of coastal cities in the Netherlands and Taiwan. Water, 5, 593-616.

http://dx.doi.org/10.3390/w5020593

[5] Dam, P.J. (2001) Sinking peat bogs: Environmental change in Holland, 1350-1550. Environmental History, 6, 32-45. http://dx.doi.org/10.2307/3985230

[6] Tjallingii, S. (2008) The water issues in the existing city. In: Hooimeijer, F. and Toorn Vrijthoof, W.V.D., Eds., More Urban Water: Design and Management of Dutch Water Cities, Urban Water Series, Taylor \& Francis/Balkema, Leiden.

[7] Tjallingii, S. (1996) Ecological conditions. Strategies and structures in environmental planning. Vol. 2, IBN Scientific Contributions, DLO Institute to Forestry and Nature Research (IBNDLO), Wageningen. 